\title{
Adaptation to climate change in the biosphere reserves: a case study of Katunskiy Biosphere Reserve, Russia
}

\section{Tatjana Yashina}

Keywords: biosphere reserve, climate change, adaptation strategy

\section{Abstract}

Climate change is increasingly recognized as the driver of biodiversity change. In recent years, the issues related to climate change have left the purely scientific realm and got on the agenda of many international organizations, programmes, conventions and initiatives seeking ways to mitigate and adapt to this phenomenon. Protected areas and biosphere reserves (BRs) in particular, focused as they are on the conservation of ecosystem services and on fostering sustainable regional development, play an important role in developing and implementing mitigation and adaptation measures and policies. This is officially recognized within the framework of the Madrid Action Plan for the BRs, adopted in 2008. It states that "MAB and WNBR bring added value through the integrated approach which is generally absent elsewhere. The role of biosphere reserves is essential to rapidly seek and test solutions to the challenges of climate change as well as monitor the changes as part of a global network. For the Natural Sciences as well as other Programme Sectors of UNESCO, biosphere reserves can be areas for demonstrating adaptation measures for natural and human systems, assisting the development of resilience strategies and practices. Buffer zones and transition areas of biosphere reserves may also be used to test many mitigation tactics and strategies". Target 24 of the Action Plan envisages using BRs as learning sites for research into, adaptation to and mitigation of climate change effects.
Profile

Protected Area

Katunskiy Biosphere Reserve

Mountain range

Altai Mountains

Country

\section{Russian Federation}

\section{Location and biophysical environment}

Katunskiy BR is located in the Altai-Sayan Ecoregion, designated as one of the WWF Global 200 Ecoregions of the World. The BR in the Central Altai mountains covers more than 600000 hectares, including 151600 hectares of intact high-altitude landscapes of its core zone. A breakdown of landscape types in the BR by acreage shows $24 \%$ glaciers and nival landscapes, $30 \%$ alpine landscapes, $43 \%$ montane forests, $2 \%$ combination of woodlands and steppes and 1\% steppes in intermountain depressions, see Figure 1. The highest peak in Siberia - Mt. Belukha (4506 m) - is located in the transition zone of the $\mathrm{BR}$.

Biodiversity in the Katunskiy BR is represented by approx. 1000 species of higher vascular plants (including 20 endangered species), 161 bird species (20 of them endangered) and 52 species of mammals ( 3 of them endangered). Habitats and important migratory routes of globally endangered species, such as the Snow leopard (Uncia uncia), Musk deer (Moschus moschiferus), Black vulture (Aegypius monachus) and Fish hawk (Pandion haliaetus) are found in the BR, particularly within the core zone. In 1998, Katunskiy BR was designated as the cluster of The Golden Mountains of Altai UNESCO World Heritage Site, nominated for its extremely rich and globally significant biodiversity.

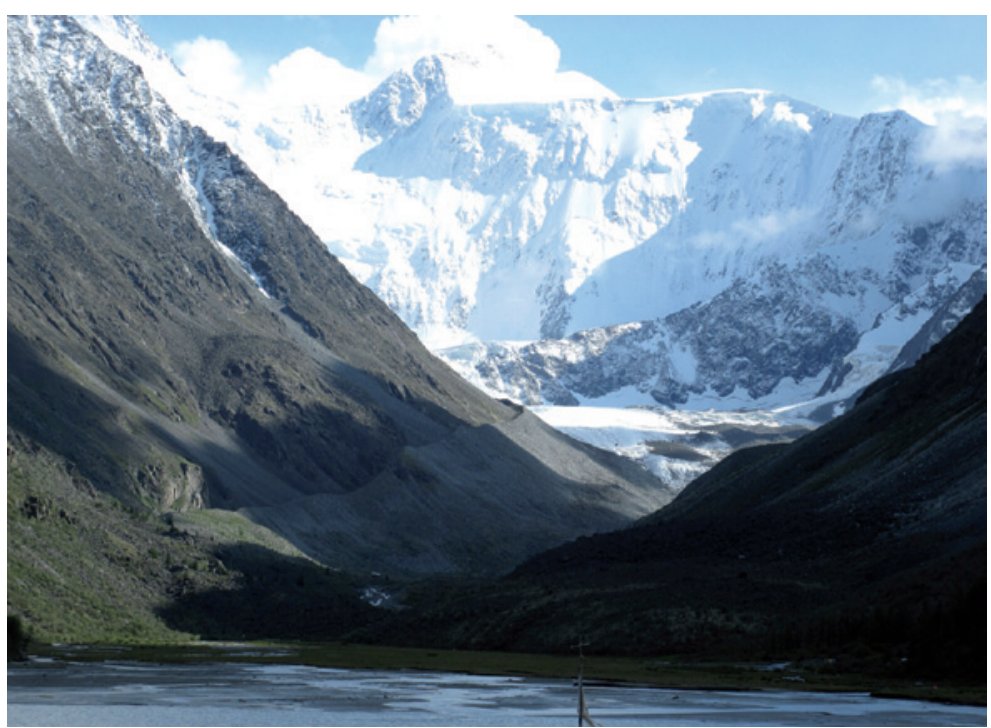

Belukha mountain from the transition zone of the BR. (C) T. Yashina

\section{Land use and socio-economic conditions}

Land use in Katunskiy BR is typical for the Altai region. Figure 2 shows the distribution of land-use types and Table 1 gives a breakdown by zone.

The local population is highly dependent on the natural resources (by hunting, fishing, collecting non-timber forest products, etc.), as was indicated by a special survey (see Yashina 2009). 


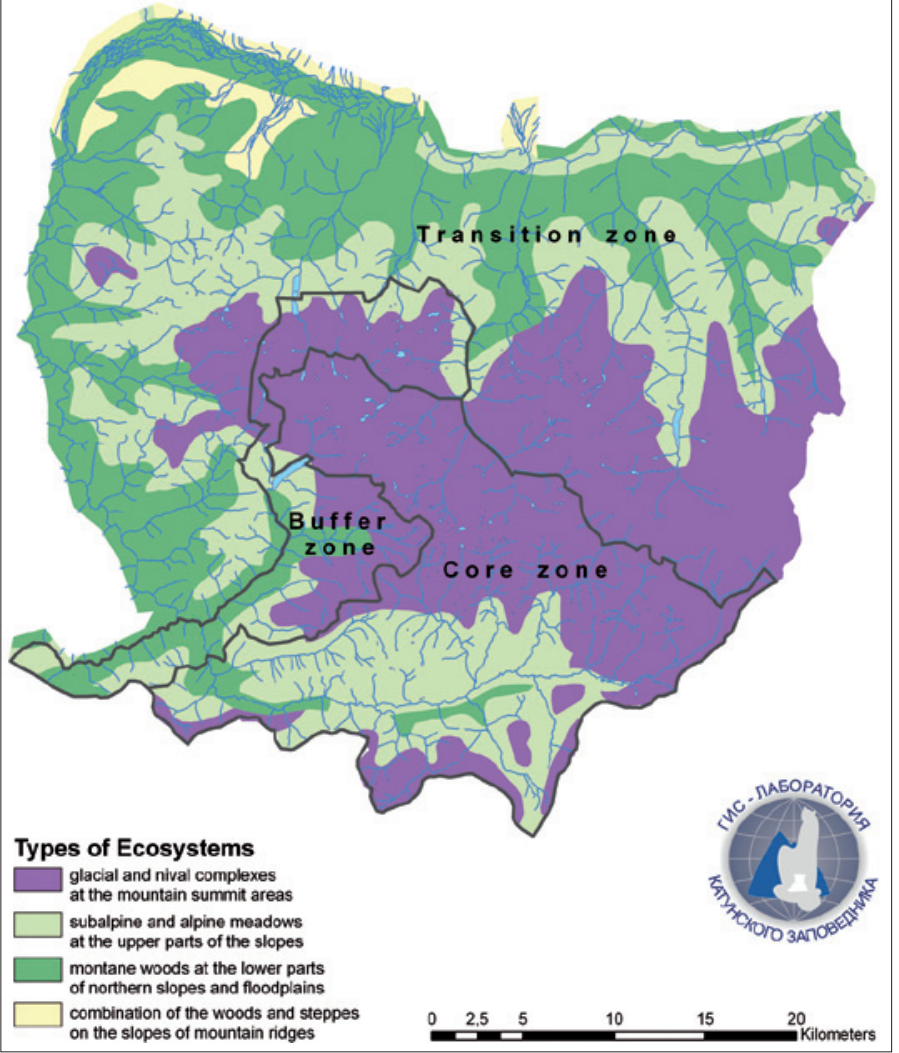

Figure 1 - Ecosystems of Katunskiy BR. (C) T. Yashina

The basic environmental impact in the transition zone is caused by the Altai wapiti (Siberian elk) farms. These are large fenced areas where animals are reared in near-natural conditions. The basic product are the antlers, which are exported to South Korea and China for the pharmaceutical industry. The major changes in ecosystems within Altai wapiti farms include changes in species composition of the native plant communities, erosion, disturbance to wildlife of the surrounding lands and obstruction of the natural migratory routes of the wild ungulates.

Being fully export-oriented, these economies are vulnerable to global market changes. The price of the

Table 1 - Breakdown of land use by zone.

\begin{tabular}{|c|c|}
\hline BR zone & Types of the land use and human activities \\
\hline Core & $\begin{array}{l}\text { Strictly protected (patrolling, researches and monitoring, } \\
\text { limited eco-tourism) }\end{array}$ \\
\hline Buffer & $\begin{array}{l}\text { - Recreation and tourism; } \\
\text { - collection of medicinal plants and non-timber forest products; } \\
\text { - hunting; } \\
\text { - fishing; } \\
\text { - apiculture; } \\
\text { - limited cattle grazing. }\end{array}$ \\
\hline $\begin{array}{l}\text { Transition } \\
\text { zone }\end{array}$ & $\begin{array}{l}\text { - } 10 \text { permanent settlements with total population of } \sim 4500 \text { people; } \\
\text { - forestry (harvesting fuel wood); } \\
\text { - Siberian elk farms; } \\
\text { - collection of non-timber products; } \\
\text { - recreation and tourism; } \\
\text { - hunting; } \\
\text { - fishing; } \\
\text { - apiculture; } \\
\text { - cattle grazing; } \\
\text { - hay meadows. }\end{array}$ \\
\hline
\end{tabular}

conserved antlers exported from the BR has varied significantly within the last 15 years - from 750 USD at the beginning of the 1990s to less than 200 USD in 2010. Because of the large areas involved, the economic success or failure of the Altai wapiti farms could significantly affect the whole BR territory through potential expansion or reduction.

Mt. Belukha - the major recreational site of the Altai mountains - is located in the transition zone. It attracts many tourists from different categories - from mountaineers to religious pilgrims following the doctrine of famous painter and philosopher Nicolas Roerich, who considered Mt. Belukha as one of the paths to mystical Shambala. The negative impact of tourism is confined to trails and camp sites and leaves $95 \%$ of the whole area unaffected. However, a further increase in visitor numbers may cause irreversible changes in the natural ecosystems if no measures on increasing the capacity of trails and camps are in place.

\section{Climate change and its effects}

Its location far from large towns, cities and industrial centers means that the core zone of Katunskiy BR represents natural ecosystems without interference from human activities. The key driver of its dynamics is climate change. The regional trend of mean annual temperature, established by analysing climate data from Barnaul weather station going back to 1835 , shows significant warming from -0.5 to $+2.3^{\circ} \mathrm{C}$. Local temperature variations are not so clear. Nevertheless, the observations from meteorological stations located within the BR show a general warming trend. Kharlamova (2010) provides an analysis of climate data for a 50 -year period from meteorological stations located at different altitudes, showing an increase of mean annual temperature by $+1.45^{\circ} \mathrm{C}$ at high elevations $(2000 \mathrm{~m})$ and by $+2.1^{\circ} \mathrm{C}$ at lower elevations within intermountain depressions (998 $\mathrm{m}$ ) during the last five decades.

Sukhova et al. (2005) point out that the most significant warming is observed in spring and winter seasons, while this trend is not so clear in summer. The warming trend is accompanied by a slight increase in annual precipitation. However, there is no clear link between trends of precipitation change at different altitudes. At the top of mountain ranges, precipitation has increased during spring and summer while there is no significant change in winter and even a decrease in autumn. Observations at river valleys show an increase of precipitation in summer, accompanied by a decrease in transitional seasons. Within intermountain depressions, a rapid increase of summer precipitation has been observed with no significant changes for other seasons.

Since there was no sophisticated modelling of regional climate change, the relevant publication by the WWF (2001) provides a general scenar- 
io for climate change in the Altai-Sayan Ecoregion. Within the next 50 years, the January temperature in most parts of the Altai-Sayan region will increase by $2-3^{\circ} \mathrm{C}$. Around Mt. Belukha, the temperature is likely to increase by $4-5^{\circ} \mathrm{C}$. At the same time, a $20 \%$ increase in precipitation is likely, especially during winters. On the whole, the second quarter of the century may see warming that is twice as fast as the warming in the first quarter.

Katunskiy BR is recognized as a water tower, where most of the discharge of the river Katun is formed. It is one of the most significant centres of modern glaciation in Siberia with 317 glaciers covering a total area of $230 \mathrm{~km}^{2}$. The amount of water trapped in the glaciers is estimated at 7370 billion tons. Recent studies (Galakhov \& Mukhammetov 1999) show that the glaciers of the Altai mountains have retreated by $19.7 \%$ during the period from 1952 to 2004. At the same time, large glaciers of the Belukha massif have lost about $15 \%$ of their area. This accelerated glacier melt causes changes in the hydrology of high-altitudinal catchments because meltwater makes up more than $50 \%$ of the total discharge of rivers at upper and middle elevations.

Ecosystems at high altitudes are particularly sensitive and vulnerable to climate change. An increase in air temperature may cause upward shifts of altitudinal belts and significant changes in vegetation and habitat patterns, especially at summit areas. Many studies demonstrate intensive forest growth and upward shift of forest vegetation by $30-60 \mathrm{~m}$ during the last 60-80 years in different regions of the world. Such a trend has been identifed for Katunskiy BR, where the upper treeline has shifted upwards by $60-100 \mathrm{~m}$ during the last 120 years (Patrusheva 2010). The pattern of ecosystem cover will also change, mostly caused by an upward shift of the treeline (by $50-100 \mathrm{~m}$ for 2090) and the subalpine shrubs (by 100-200 m) (Mikhailov et al. 1992). This will cause a fragmentation of alpine ecosystems.

In general, Parfenova \& Chebakova (2000) forecast a decrease of the area of mountain tundra ecosystems by $18 \%$, subalpine shrub ecosystems by $4 \%$ and an increase of mountain woodland communities by $15 \%$ and steppes by $3.5 \%$

With regard to mammals, the area is likely to see more unfavourable winter conditions for ungulates and predatory mammals and force large seasonal migrations upon them. A few years of particularly heavy snowfalls may then be followed by the massive death of animals. Due to the intensification of the dry period in summer, the ungulates will be forced to spend more time on high mountain grasslands, increasing competition with cattle.

\section{Adaptation strategy}

In 2009, within the UNESCO MAB GLOCHAMOST project, the outlines of the climate change adaptation

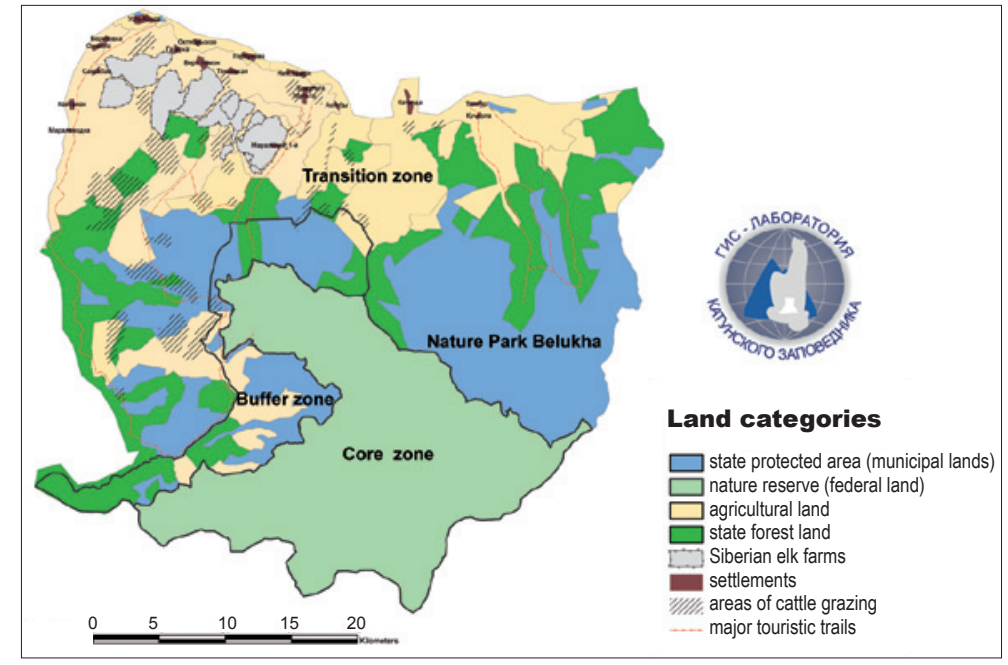

Figure 2 - Distribution of land-use types in the Katunskiy BR (C) T. Yashina

strategy for Katunskiy BR were developed, based on a participatory approach (Yashina 2009). The general aim of the strategy is to maintain ecosystem services of the territory of Katunskiy BR and to reduce the vulnerability of local communities to global change.

The guiding principles for global change adaptation strategy for the BR are as follows:

- using adaptive management to maintain flexibility; - monitoring and tracking changes in weather, hydrology, ecosystems and land use;

- identifying possible futures through modelling;

- maintaining the resilience of ecosystems and minimizing stress at the core zone;

raising public awareness on the effects of global change;

- implementing model projects on sustainable use of natural resources in changing conditions.

\section{Key objectives include:}

Refining the monitoring programme to detect the signals of the effects of climate change and land use on the natural ecosystems. This monitoring system, guided by the GLOCHAMORE Research Strategy, has been implemented in Katunskiy BR since 2006. It is focused on complementary monitoring of vulnerable ecosystems and components of the environment. Key targets of this activity are:

- meteorological parameters along altitudinal gradients;

- water balance of high-altitudinal catchments;

- glaciers;

- snow cover;

- alpine ecosystems (Pauli et al. 2004);

- ecotone of the upper treeline;

species composition and productivity of typical vegetation communities along altitudinal gradients; populations of large mammals;

changes in ecosystems caused by human activities (effects of recreation and grazing).

Strengthening the partnerships with research institutions for modelling changes in hydrology, 
biodiversity and ecosystems. In 2006, the Research Consortium of the Katunskiy BR was established and includes seven universities and institutes who conduct monitoring and research activities within the BR according to the general medium-term research plan adopted by the BR administration. The results of all these studies are intergrated into the joint database and serve as the baseline for further modelling.

Providing migratory routes for large mammals by implementing the concept of connectivity conservation (Worboys et al. 2010) and strengthening crossborder cooperation with Katon-Karagaiskiy National Park (Kazakhstan). The cross-border cooperation was initiated in 2004 and includes a number of joint activities, such as sharing information in the field of law enforcement and breakers, research expeditions, educational activities for local people on both sides of the border, etc. Eventually, a cross-border biosphere reserve will be established.

Developing educational and interpretative programmes on climate-change related issues for different target groups (children, farmers, decision makers, visitors, etc.).

Implementing model projects on (1) alternative energy supply (equipping ranger stations and high-altitudinal apiaries with solar batteries, mini-hydropower schemes and solar cookers) (2) sustainable tourism (focused on the most stressed areas in the transition zone) and (3) diversification of vulnerable economies (Altai wapiti farms). The latter include developing tourism within Altai wapiti farms, marketing additional Altai wapiti products such as meat, setting up small enterprises for processing raw materials into pharmaceutical products, etc. These projects are implemented with support from the UNDP-GEF project Biodiversity Conservation in the Russian Portion of the AltaiSayan Ecoregion, WWF Russia, US Fish and Wildlife Service and other NGOs.

\section{Conclusion}

The Climate Doctrine of the Russian Federation, adopted officially in 2009, recognizes that the development and implementation of long-term mitigation and adaptation measures are among the key objectives of climate-related policy. However, for the protected areas, climate change adaptation is a brand-new type of activity. Currently, the regional adaptation strategy for the Russian portion of the Altai-Sayan Ecoregion is being developed with support from the International Climate Initiative of the German government. This experience of the Katunskiy BR could be considered a pilot activity for Russia, targeted at the management of protected areas under conditions of climate change. This adaptation strategy will be developed further within the UNDP-ICI project mentioned above.

\section{Acknowledgments}

This article is based on the assessment report on the Katunskiy State Nature BR produced within the GLOCHAMOST project, funded by the UNESCO MAB programme. This organization, and particularly Dr. Thomas Schaaf, is gratefully acknowledged.

\section{References}

Galakhov, V.P. \& R.M. Mukhammetov 1999. Glaciers of the Altai. Novosibirsk. [In Russian]

Kharlamova, N. 2010. Trends of climate change in the region. In: Tashina, T. (ed.), Climate Change and Connectivity Conservation in the Altai-Sayan Ecoregion: 10-25. [In Russian]

Madrid Action Plan for Biosphere Reserves. UNESCO MAB, 2008. Available at http://unesdoc. unesco.org/images/0016/001633/163301e.pdf (accessed 13/03/2011)

Mikhailov, N.N., K.V. Chistyakov \& Y.P. Selverstov 1992. Geoecology of the intermountain depressions. Lenin$\operatorname{grad}$ [In Russian]

MRI (eds.) 2005. GLOCHAMORE - Global Change and Mountain. Regions Research Strategy.

Parfenova, E. \& N. Chebakova 2000. Projected changes of vegetation of the Altai Mountains under climate warming and compilation of projection maps. Geobotanic Mapping, 1998-2000: 26-31. [In Russian]

Patrusheva, T. 2010. Dendrological indication of climate change in the high-altitudinal zone of the Altai. In: Tashina, T. (ed.), Climate Change and Connectivity Conservation in the Altai-Sayan Ecoregion: 102-106. [In Russian]

Pauli, H., M. Gottfried, D. Hohenwallner, K. Reiter, R. Casale \& G. Grabherr 2009. The Gloria Field Manual. Multi-Summit Approach. Available at: http:/ / www.gloria.ac.at/downloads/GLORIA_MS4_Web_ english.pdf (accessed 07/09/2010)

Sukhova M.G., N.A. Kocheeva \& O.V. Zhuravleva 2005. Reconstruction, modern trends and possible future scenarios of climate change. A case study of Katunskiy Ridge. In: Yaskov, M. (ed.), Geoecology of the Altai-Sayan mountain region 2: 161-165. [In Russian]

Worboys G.L., W.L. Frensis \& M. Lockwood (eds.) 2010. Connectivity Conservation Management: A Global Guide.

WWF 2001. Ecoregional Climate Change and Biodiversity Decline, Issue 1, Altai-Sayan Ecoregion.

Yashina, T. 2009. Global Change in Mountain Sites (GLOCHAMOST) - Coping Strategies for Mountain Biosphere Reserves. Assessment report on the Katunskiy State Nature Biosphere Reserve (Russian Federation).

\section{Author}

\section{Tatjana Yashina}

Russia, 649490, Altai Republic, Ust-Koksa, Zapovednaya st. 1. Katunskiy Biosphere Reserve yashina_t@rambler.ru 